\title{
CURRENT TRENDS IN SLOVAK LEGISLATION REGULATING RENEWABLE ENERGY PRODUCTION
}

\section{Ondrej Beňuš* , Dominika Čeryová}

Slovak University of Agriculture in Nitra, Slovak Republic

Renewable energy production is one of key actions undertaken by the EU to lower its dependency on energy imports from third countries. Renewable energy is not competitive compared to fossil fuels at this moment. Under these circumstances, there is a need for an effective legal regulation. The EU has set main targets relating renewable energy use in the directive (EU) 2018/2001. Slovak policymakers have recognized these new targets. The main objective of the paper is to examine the latest changes to the Slovak legal regulation of the renewable energy production with focus on electricity production. We analyse changes made by the amendment of the Act No. 309/2009 Coll. and provide a short explanation of new instruments.

Keywords: Act No. 309/2009 Coll., renewable energy, electricity

\section{Introduction}

Energy is a shaping development in each country and it is essential for economic growth. The European Union is highly dependent on energy imports. The gap between the demand for energy and production capacity is causing the fact that the $\mathrm{EU}$ is more vulnerable to crises in the energy markets (Gökgöz and Güvercin, 2018). There is a common effort to change this energy dependency of the European Union. One of the key instruments is the use of renewable energy sources. Policymakers have been supporting the offensive renewable energy policy within the EU for many years now. On the other hand, the use of arable land for renewable energy production has brought intensive debate whether this is an adequate way. There is the general opinion that using land for renewable energy production is causing the growth of prices in agriculture (and in the end, the growth of foodstuff prices). When considering all variables influencing prices of agricultural products, there is enough research evidence that renewable energy is not the primary variable causing this growth (Makutenas et al., 2018). Current renewable energy policy targets implemented in developed countries accept limits provided by the land use and available research has shown achievability of proposed targets (Oliver and Khanna, 2017).

While electricity represents the second most important market for renewable energy use (European Environment Agency, 2018), in the Slovak Republic, it has the major share (Bozsik and Magda, 2018). Electricity produced from scare sources creates dilemma for policymakers. Demand for electricity is rising and the availability of scare sources is limited. On the other hand, electricity produced from renewable energy is limitless and even the latest research shows a direct positive connection between electricity generated from renewable sources and GDP per capita (Armeanu and Vintilă and Gherghina, 2017).

The development of renewable energy is very dependent on legislation available in each country. Renewable energy cannot compete with fossil fuels at this time. There is imminent need for a favourable legal regulation that will improve the competitiveness of renewable energy. At this time, we can find five main legislative mechanisms supporting the production of renewable energy (Paska and Surma, 2014):

$\square$ Investment subsidies.

$\square$ Fixed price mechanisms.

$\square$ Fixed premium mechanisms. $\square$ Quota system based on auctions.

$\square$ Quota system based on tradable green certificates.

Legislation can also lower the competitiveness of renewable energy. According to Outka (2012), it can be:

$\square$ lagging development of affirmative new law to support renewable energy,

$\square$ existing law fashioned in support of a pre-renewables energy sector.

We are investigating current changes in the Slovak legislation regulating the renewable energy production and use.

\section{Material and methods}

We are investigating the national legislation related to renewable energy support. First, we are going to examine the EU law dedicated to the renewable energy. Based on the throughout evaluation of EU primary and secondary law, we identify the key elements of EU renewable energy legislation. Based on these key elements, we are going to identify the national legislation responsible for transposition of rules set at EU level.

The second aim of the article is to compare newly adopted legislation regulating renewable energy support in reflection of the Directive (EU) 2018/2001. We decided to start with a conceptual analysis of the renewable energy legislation at the national level. We use the descriptive method to identify changes made by the amendment of the Act No. 309/2009 Coll. in this article.

The main sources are legislative acts of the EU and the Slovak Republic. We also want to put the legislative changes into the context of economic targets set by the European renewable energy policy. For this reason, we are going to use statistical data available in the Eurostat database.

\section{Results and discussion}

Statistical data available in the Eurostat database show significant growth of renewable energy market share in the EU between years 2004 and 2016. However, the total share of the renewable energy achieved up to the last year was observed well below the target of $20 \%$ (should be achieved in 2020). When we compare all Visegrad group countries, we will come to different results. The Czech Republic and Hungary have fulfilled targets set by the 


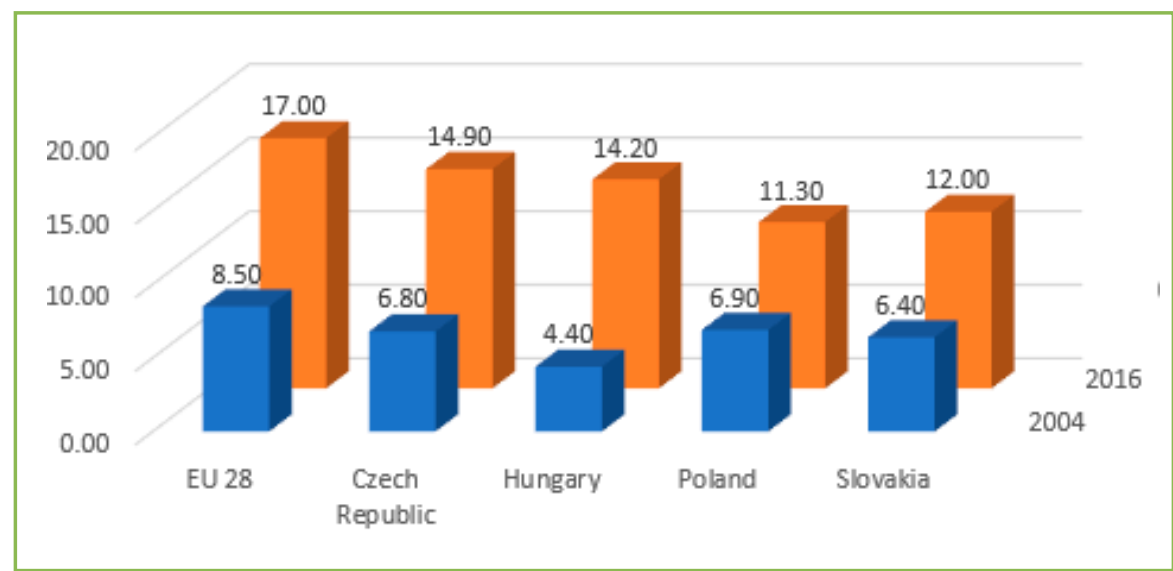

Figure 1 Market share of renewable energy on total consumption in V4 countries from 2004 to 2016 in $\%$

Source: Eurostat, data processed by the author

Directive already in 2016. Slovakia is only 1\% below the target set by the directive. Poland was the worst performer among all V4 countries. This country has the highest target (15\%) set by the directive but the observed growth potential was the weakest.

The EU started its legislative actions in the field of renewable energies in the 1990s (Fouquet and Johansson, 2008).

Joining the EU has brought new responsibilities for the lawmakers in the Slovak Republic. European law has been part of our national law system since 2004. The degree of EU law integration is set by the primary law. The Treaty on the functioning of the EU (TFEU) divides competences of the EU into (Article 3,4 and 6 of the TFEU):

\section{$\square$ Exclusive. \\ $\square$ Shared. \\ $\square$ Cooperating competences.}

The major legislation work of the $\mathrm{EU}$ is visible in exclusive and shared competences of the EU where the EU is mainly adopting legally binding acts (article 288 TFEU). Our object of research (energy) belongs to the shared competences of the EU and Member states (Article 4 Section 2 (i) TFEU). Following Article 2 TFEU, the EU may adopt binding legislative acts in this field. Member states should only fill "the gaps" in legislation by adopting national legislative acts. Following the legislative praxis, the $\mathrm{EU}$ adopts directives in this case. Directives represent legislative rules that are binding as to the results set by the legislative act. This means, they are not directly applicable and Member states are free in choosing forms and methods.

The EU has adopted its latest directive (directive (EU) 2018/2001) on the promotion of the use of energy from renewable sources on December $11^{\text {th }}, 2018$. The new directive will be in force with the previous directive (2009/28/ $\mathrm{EC}$ ) on the promotion of the use of energy from renewable sources which was adopted on April $23^{\text {rd }}, 2009$. Directive $2009 / 28 /$ EC will be fully repealed by the directive (EU) 2018/2001 on June $30^{\text {th }}, 2021$.

The directive (EU) 2018/2001 has been adopted as a part of "Clean Energy for All Europeans Package" and represents a new policy framework in the field of renewable energy. It should:

1. provide long-term certainty for investors and speed up procedures to receive permits for projects;

2. put the consumer at the centre of the energy transition with a clear right to produce their own renewable energy;

Table 1 Comparison of national overall targets for the share of energy from renewable sources within V4 countries

\begin{tabular}{|l|c|c|}
\hline Country & \% share in 2005 & \% share in $\mathbf{2 0 2 0}$ \\
\hline Czech Republic & 6.1 & 13 \\
\hline Hungary & 4.3 & 13 \\
\hline Poland & 7.2 & 15 \\
\hline Slovak Republic & 6.7 & 14 \\
\hline
\end{tabular}

Source: Directive (EU) 2018/2001
3. increase competition and market integration of renewable electricity;

4. accelerate the uptake of renewables in the heating/cooling and transport sectors;

5. strengthen the sustainability of bio-energy and promote innovative technologies.

The general aim of the new directive is to achieve a $32 \%$ share of renewable energy on the whole amount of energy produced within the EU. This is a significant increase compared to a $20 \%$ share set by the previous directive 2009/28/ EC. In both directives, the aim set for the Slovak Republic remains the same and represents 14\% (Tab. 1) share of renewable energy until 2020.

Although the aimed share of renewable energy has not been changed, there are new challenges to be addressed. As we mentioned before, the main aim of directives is to set goals. The implementation process is chosen freely by each Member state. According to these criteria, at least some form of national legislation is required.

Slovak legislation regulating the renewable energy has reflected rules set by the abovementioned directives by adopting the Act No. 309/2009 Coll., on the Support of Renewable Energy Sources as amended. In fact, this legal act has been revised by the Act. No. 309/2018 Coll. Last revision has brought a new approach to regulation of the renewable energy within the Slovak Republic.

Our main aim within this article is to focus on newly adopted legal regulation of renewable electricity production. This corresponds to all six sources of energy:
$\square$ wind energy,
$\square$ solar energy,
$\square$ geothermal energy,
$\square$ hydro-power energy,
$\square$ biomass energy,
$\square$ biogas energy.

Basic definitions related to the producers of electricity from renewable energy and combined production will remain unaffected also after the adoption of the new legal regulation.

The producer of electricity from renewable energy sources is a producer of electricity that produces electricity from renewable energy sources (Art. 2 par. 1 Letter c) of the Act No. 309/2009 (oll.).

Combined production represents a technological process where the production of (Art. 2 par. 2 Letter b) of the Act No. 309/2009 Coll.):

$\square$ electricity and heat, 
$\square$ mechanical energy and heat,

$\square$ mechanical energy, heat and electricity

$\square$ takes part at the same moment.

This combined production is further decomposed according to the amount of electricity produced in (Art. 2 par. 2 Letter g) h) i) of the Act No. 309/2009 Coll.):

1. the combined production of very small outputs which represents combined production in a cogeneration plant with installed electrical power of less than $50 \mathrm{~kW}$,

2. the combined production of small outputs which represents combined production in a cogeneration plant with an installed electrical output of an installation of $50 \mathrm{~kW}$ up to $1 \mathrm{MW}$,

3. the combined production of large outputs which represents combined production in a cogeneration plant with an installed electrical output of $1 \mathrm{MW}$, including.
Newly adopted regulation on renewable energy sources has brought the definition of a new type of renewable energy producers. The Act No. 309/2019 Coll. as amended on January 1 $1^{\text {st }}, 2019$ contains a provision on the local source. A local source is a renewable electricity generation facility that generates electricity to cover the consumption of a collection point and whose total installed power is up to $500 \mathrm{~kW}$ but not more than the maximum reserved capacity of such a collection point (Art. 2 par. 3 Letter $n$ ) of the Act No. 309/2009 Coll.). This type of renewable energy producers should be primarily represented by small energy producers consuming the whole amount of renewable energy produced at their own facilities. This means that production of the facility must be under its own consumption. The possibility of selling overproduction is prohibited by the law. The second requirement set by the law is the total installed power up to $500 \mathrm{~kW}$.

Lawmakers have set a broad range of support mechanisms (as shown in the table 2) to secure fulfilment of targets set by the directive $2009 / 28 / \mathrm{EC}$ or later by the directive (EU) 2018/2001.

Table 2 Slovak renewable energy regulation reflecting legislative changes valid from January $1^{\text {st }}, 2019$

\begin{tabular}{|c|c|c|c|}
\hline \multicolumn{2}{|c|}{ Act No. 309/2009 Coll. in force until January $31^{\text {st }}, 2018$} & \multicolumn{2}{|c|}{ Act No. 309/2009 Coll. adopted on January 1 1', 2019} \\
\hline Instrument & Conditions & Instrument & Conditions \\
\hline $\begin{array}{l}\text { Preferential (connection, } \\
\text { access and transfer) }\end{array}$ & all producers & $\begin{array}{l}\text { Preferential (connection, } \\
\text { access and transfer) }\end{array}$ & no change \\
\hline $\begin{array}{l}\text { Electricity collection } \\
\text { by the provider of the } \\
\text { regional distribution } \\
\text { system }\end{array}$ & $\begin{array}{l}\text { 1. total installed output up to } 125 \mathrm{MW} \\
\text { 2. total installed output up to } 200 \mathrm{MW} \text { (at least } 30 \% \text { of renewable } \\
\text { energy share or at least } 40 \% \text { of gas produced as a byproduct of the } \\
\text { metallurgical process) } \\
\text { 3. sub charge applicable if: } \\
\text { a) total installed output is up to } 5 \mathrm{MW} \text { (if total output is above } \\
5 \mathrm{MW} \text {, only the part corresponding with } 5 \mathrm{MW} \text { production is } \\
\text { considered) } \\
\text { total installed output is up to } 15 \mathrm{MW} \text { and the source of } \\
\text { energy is wind (if total output is above } 15 \mathrm{MW} \text {, only the part } \\
\text { corresponding with } 15 \mathrm{MW} \text { production is considered) } \\
\text { total installed output is over } 5 \mathrm{MW} \text { (if the total amount of } \\
\text { usable heat produced in combined production distributed } \\
\text { for technological purposes is up to } 40 \% \text { ) } \\
\text { total installed output is over } 5 \mathrm{MW} \text { (if the total amount } \\
\text { of usable heat produced in combined production for } \\
\text { technological purposes is up to } 40 \% \text { and the renewable } \\
\text { energy share is more than } 20 \% \text { ) } \\
\text { total installed output is over } 10 \mathrm{MW} \text { (if the total amount } \\
\text { of usable heat produced in combined production for } \\
\text { technological purposes is up to } 40 \% \text { and the renewable } \\
\text { energy share is more than } 30 \% \text { ) } \\
\text { total installed output is over } 5 \mathrm{MW} \text { (if the total amount } \\
\text { of usable heat produced in combined production for } \\
\text { technological purposes is up to } 40 \% \text { and the renewable } \\
\text { energy share is more than } 30 \% \text { ) } \\
\text { total installed output is over } 5 \mathrm{MW} \text { (if the total amount } \\
\text { of usable heat produced in combined production for } \\
\text { technological purposes is more than } 40 \% \text { ) }\end{array}$ & $\begin{array}{l}\text { Purchase of electricity by } \\
\text { the buyer of electricity }\end{array}$ & $\begin{array}{l}\text { total installed output up to } 250 \mathrm{KW} \text {, if produced in combined } \\
\text { production (water energy, geothermal energy, biogas, landfill } \\
\text { gas, gas from sewage treatment plants) }\end{array}$ \\
\hline $\begin{array}{l}\text { Taking responsibility } \\
\text { for deviation }\end{array}$ & $\begin{array}{l}\text { all producers with a total installed output from } 10 \mathrm{KW} \text { up to } 1 \mathrm{MW} \text {. If } \\
\text { the only renewable source is the solar energy, this support will be only } \\
\text { provided to producers with total installed output up to } 30 \mathrm{KW}\end{array}$ & $\begin{array}{l}\text { Taking responsibility for } \\
\text { deviation }\end{array}$ & $\begin{array}{l}\text { total installed output up to } 250 \mathrm{KW} \text {, if produced in combined } \\
\text { production (water energy, geothermal energy, biogas, landfill } \\
\text { gas, gas from sewage treatment plants) }\end{array}$ \\
\hline- & - & Bonus & all producers with the total installed output from $10 \mathrm{~kW}$ to $50 \mathrm{MW}$ \\
\hline
\end{tabular}


Preferential connection, access and transfer (Art. 3 par. 1 Letter a) of the Act No. 309/2009 Coll.) are guaranteed to all electricity producers who use renewable energy as source energy. After the revision of the investigated act, there are no changes in this field introduced to the legislation after January $1^{\text {st }}, 2019$. This instrument is one of the key determinants regulating the competitiveness of renewable energy when grid connection represents elementary assumption for renewable energy development (Painuly, 2000).

Electricity collection and surcharge were using common selection criteria. The first restriction was set to $125 \mathrm{MW}$ (or $200 \mathrm{MW}$ respectively) for electricity producers until December $31^{\text {st }}, 2019$. Surcharge system was using a relatively complicated system of restrictions (see the table 2) bound to combined production and renewable energy use. Legislative changes introduced by the amendment of the Act No. 309/2009 Coll. are relatively significant in this case. The purchase of electricity and system of surcharges has been divided and individual criteria are used. The $250 \mathrm{~kW}$ total allowed output introduced by the new legislation is significantly lower compared to previous legislation. Surcharge system has been changed, too. Lawmakers granted access to the system of surcharges to the producer with a total output of $500 \mathrm{~kW}$ or $1 \mathrm{MW}$, respectively.

The same conditions as earlier mentioned conditions for the purchase of electricity are applied to the responsibility taking for deviation.

The bonus represents a new benefit first introduced by the amendment of the Act No. 309/2009 Coll. that entered into force on January $1^{\text {st }}, 2019$.

Amendment of the Act No. 309/2009 Coll. has also brought significant changes in the length of the support.

The first benefit guaranteed to all renewable electricity producers is represented by the preferential connection, access and transfer. This benefit has been brought to the Slovak legislation as the result of EU Directive transposition. The directive has set binding rules for the Member states relating administrative procedures, regulations and codes. The Slovak Republic has acknowledged this legal norm and is providing preferential connection, access and transfer conditions to electricity producers who have produced this electricity from renewable sources. These preferential conditions have not been changed by the amendment of the Act No. 309/2009 Coll.

Next benefit, that has been brought to the Slovak law by the adoption of the Act No. 309/2009 Coll., is oriented towards the collection of the electricity. The mentioned legal act provided electricity collection by the provider of regional distribution system for up to 15 years. After the amendment of the Act No. 309/209 Coll., there are still 15 years of protection. The very significant change has been brought to the legislation by the replacement of the provider of the regional distribution system. The Act No. 309/2009 Coll., which has been in force since January $1^{\text {st }}, 2019$, has established a completely new system. Today, the electricity must be purchased by the buyer of the electricity. This system will establish auctions and the main objective is to select only electricity producers with the lowest final price. Lowering the final price of renewable energy is a key element within all Member states when the costs of renewable energy are the highest in the EU compared the United States or China (Saguan and Meeus, 2014). The state is following a clear path by this system of actions when its main objective is the creation of a marketoriented selection.

Surcharge and taking responsibility for deviation were not affected and the 15-year period of protection remains unchanged after January 1 ${ }^{\text {st }}, 2019$.

A new addition to the above-mentioned legal act is represented by a possibility to obtain a bonus for producing electricity from renewable energy sources. The bonus is guaranteed for 15 years after receiving an acknowledgement from the state.

\section{Conclusion}

In this manuscript, we have been following the current trends in the Slovak legislation introduced on January $1^{\text {st }}$, 2019. Slovakia as a Member state of the $\mathrm{EU}$ is responsible for an adequate implentation of EU renewable energy policy. Slovak policymakers have adopted the revised version of the act regulating renewable energy following latest changes in the EU law. The new EU legislation did not affect the target set for the Slovak Republic. On the other hand, the global target set for the EU has been increased to 32\%. Each Member state is obligated to take adequate actions and take part in this action.

The Slovak legislation adopted new instruments and definitions in order to increase the market share of renewable energy.

The local source is a completely new definition in the Slovak law regulating the renewable energy. This new definition regulates the use and collection of electricity produced by small producers. The main objective is to lower the administrative demand for producers who use all produced electricity.

The system of auctions will be put to the test and only the time will show its effectiveness. It should bring clear methods when choosing suppliers from all available electricity producers. This mechanism should, at least in theory, bring lower prices. Auctions are used only in a few countries. Current experience from Germany has shown that introduction of this mechanism requires a lot of effort. Based on this knowledge, we can presume that direct implementation of this system may cause difficulties in the first years. Promised price reduction is questionable and we have to wait until the first auctions are enclosed.

Table 3 Changes in the length of support set by the Act No. 309/2009 after January $1^{\text {st }}, 2019$

\begin{tabular}{|c|c|c|c|}
\hline \multicolumn{4}{|l|}{ Length of support } \\
\hline \multicolumn{2}{|c|}{ Act No. 309/2009 Coll. in force until January $31^{\text {st }}, 2018$} & \multicolumn{2}{|c|}{ Act No. 309/2009 Coll. adopted on January 1't, 2019} \\
\hline Instrument & Conditions & Instrument & Conditions \\
\hline $\begin{array}{l}\text { Preferential (connection, access and } \\
\text { transfer) }\end{array}$ & no restriction & Preferential (connection, access and transfer) & no restriction \\
\hline $\begin{array}{l}\text { Electricity collection by the provider } \\
\text { of the regional distribution system }\end{array}$ & 15 years & $\begin{array}{l}\text { Purchase of electricity by the buyer of } \\
\text { electricity }\end{array}$ & 15 years (max. until December $31^{\text {st }}, 2033$ ) \\
\hline Surcharge & 15 years & Surcharge & 15 years \\
\hline Taking responsibility for deviation & 15 years & Taking responsibility for deviation & 15 years (max. until December $31^{\text {st }}, 2033$ ) \\
\hline- & - & Bonus & 15 years \\
\hline
\end{tabular}

Source: Act. No. 309/2009 Coll. amended by the Act No. 268/2017 Coll. And Act No. 309 Coll. amended by the Act No. 309/2018 Coll. 
The bonus is the last new introduction to the renewable energy legislation in the Slovak Republic. This instrument should create stable revenues for renewable energy producers.

For the successful implementation of renewable energy use, there are also other areas for improvement. Well discussed problem is storage of the overproduction (Wagner, 2014) and the legal regulation of transmission mechanisms (Saguan and Meeus, 2014). This area should be at the forefront when preparing new European initiatives.

\section{References}

Act No. 309/2009 Coll., on the support of renewable energy sources, as amended.

Act No. 268/2017 Coll. amending and supplementing Act no. 98/2004 Coll. on Excise Duty on Mineral Oil, as amended, and amending Act no. 309/2009 Coll. on support of renewable energy sources, as amended.

Act No. 309/2018 Coll., amending and supplementing Act no. 309/2009 Coll. on the on the support of renewable energy sources and on Amendments to Certain Acts, as amended.

ARMEANU, D. - VINTILĂ, G., - GHERGHINA, Ş. 2017. Does renewable energy drive sustainable economic growth? multivariate panel data evidence for EU-28 countries. In Energies, vol. 10, 2017, no. 3, 381 p. DOl: 10.3390/en10030381.

BOZSIK, N. - MAGDA, R. 2018. Analysis of Energy Consumption of the Visegrad Countries. In Visegrad Journal on Bioeconomy and Sustainable Development, vol. 7, 2018, no. 2, pp. 36-41. D0l: 10.2478/vjbsd-2018-0007.

DIRECTIVE 96/92/EC concerning common rules for internal market in electricity.

DIRECTIVE 2009/28/EC of the European Parliament and of the Council of 23 April 2009 on the promotion of the use of energy from renewable sources and amending and subsequently repealing Directives 2001/77/EC and 2003/30/EC.

DIRECTIVE (EU) 2018/2001 of the European Parliament and of the Council of 11 December 2018 on the promotion of the use of energy from renewable sources.

EUROPEAN ENVIRONMENT AGENCY: Renewable energy in Europe - 2018. Recent growth and knock-on effects. 2018. 77p. ISBN 978-92-9480-044-2. DOI: 10.2800/03040.

EUROSTAT. Available at: https://ec.europa.eu/eurostat/statisticsexplained/index.php/ Renewable energy statistics\#Share of energy available from renewable sources highest in Latvia and Sweden
FOUQUET, D. - JOHANSSON, T. B. 2008. European renewable energy policy at crossroads Focus on electricity support mechanisms. In Energy policy, vol. 36, 2008, no. 11, pp. 4079-4092. DOI: https://doi.org/10.1016/i.enpol.2008.06.023

GÖKGÖZ, F. - GÜVERCIN, M. T. 2018. Energy security and renewable energy efficiency in EU. In Renewable and Sustainable Energy Reviews, 2018, no. 96, pp. 226-239.

MAKUTENAS, V. - MICEIKIENE, A. - SVETLANSKÁ, T. - TURČEKOVÁ, N. ŠAUČIŪNAS, T. 2018. The impact of biofuels production development in the European Union. In Agricultural Economics, vol. 64, 2018, no. 4, pp. 170-185. DOI: 10.17221/285/2016-AGRICECON

OLIVER, A. - KHANNA, M. 2017. Demand for biomass to meet renewable energy targets in the United States: Implications for land use. In GCB Bioenergy, vol. 9, 2017, no. 9, pp. 1476-1488. D0l: https://doi.org/10.1111/gcbb.12437

OUTKA, U. 2012. Environmental law and fossil fuels: Barriers to renewable energy. In Vand. L. Rev., 2012, no. 65, 1679 p.

PAINULY, J. P. 2001. Barriers to renewable energy penetration; a framework for analysis. In Renewable energy, vol. 24, 2001, no. 1, pp. 73-89. D0I: 10.1016/509601481(00)00186-5

PASKA, J. - SURMA, T. 2014. Electricity generation from renewable energy sources in Poland. In Renewable Energy, 2014, no. 71, pp. 286-294. D0l: 0.1016/j. renene.2014.05.011

POGGI, F. - FIRMINO, A. - AMADO, M. 2018. Planning renewable energy in rural areas: Impacts.

SAGUAN, M. - MEEUS, L. 2014. Impact of the regulatory framework for transmission investments on the cost of renewable energy in the EU. In Energy Economics, 2014, no. 43, pp. 185-194. D0I: 10.1016/j.eneco.2014.02.016.

Treaty on European Union.

Treaty on the Functioning of the European Union.

WAGNER, F. 2014. Considerations for an EU-wide use of renewable energies for electricity generation. In The European Physical Journal Plus, vol. 129, 2014, no. 10, 219 p. DOI: 10.1140/epjp/i2014-14219-7.

\section{Contact address}

Mgr. Ing. Ondrej Beňuš, PhD., Faculty of Economics and Management, Slovak University of Agriculture in Nitra, Tr. A. Hlinku 2, 94976 Nitra, phone.: +421 3764145 83, e-mail: ondrej.benus@uniag.sk 